6. Василів С.С. Правові колізії підвідомчості розгляду справ про адміністративні правопорушення. URL : http://science.lpnu.ua/sites/default/files/journal-paper/2017/jun/4981/ vnulpurn201683730.pdf.

7. Рабінович П.М. Основи загальної теорії права і держави : навчальний посібник ; 3-є вид., змін. і доп. Київ : ІСДО, 1995. 100 с.

8. Мірошниченко А.М. Колізії в правовому регулюванні земельних відносин в Україні ; 2-е вид., перероб. і доп. Київ : Алерта ; КНТ ; ЦУЛ, 2010. 270 с.

9. Портнов А.В., Москалюк О.В. Види колізій у законодавстві України. Юрист України. 2012. № 1, 2. C. 5-12.

10. Теличко О.А., Іванюк Н.В. Причини виникнення колізій. URL : http://www.lj.kherson.ua/ 2016/pravo06/part_1/11.pdf.

11. Свиридюк Н.П. Юридичні колізії як властивість законодавства перехідного періоду. URL : http://www.apdp.in.ua/v58/12.pdf.

12. Капліна О.В. Колізії норм кримінально-процесуального права і шляхи їх подолання. URL : http://univer.km.ua/visnyk/1245.pdf.

13. Бойко В. Загальнотеоретичний аналіз співвідношення понять «колізія правових норм» та «конкуренція правових норм». URL : http://dspace.nbuv.gov.ua/bitstream/handle/ 123456789/39578/07-Boyko.pdf?sequence $=1$.

14. Матузов Н.И. Коллизии в праве: причины, виды и способы разрешения. Правоведение. 2000. № 5. C. 231-232.

15. Погребняк С.П. Про колізії в законодавстві. Вісник Академії правових наук України. 2003. № 1(32). C. 26-33.

16. Єрьоменко В.В. Поняття та види колізій в правовому регулюванні трудових та пов'язаних із ними відносин. URL : www.irbis-nbuv.gov.ua'irbis_nbuv'cgiirbis_64.

УДК 340.1

DOI https://doi.org/10.32844/2618-1258.2019.5-1.3

ВЕКЛИЧ В.О.

\title{
НОРМИ ПРАВА І НОРМИ МОРАЛІ ЗА СУЧАСНИХ УМОВ: ПОТЕНЦІАЛ ДЛЯ РОЗВИТКУ АБО ДЕГРАДАЦІЇ
}

У статті подано результати дослідження практичних особливостей норми права і норми моралі за сучасних умов, які пов'язані з їх регуляторним впливом на суспільні відносини. Встановлено деякі практичні особливості виникнення норм моралі та норм права, а також опрацьовано релевантний теоретичний матеріал, який стосується дефініцій окреслених норм. Подано загальну характеристику суспільних відносин за умов реалізації правового регулювання у зв'язку з опосередкованістю через узагальнені моделі з урахуванням однотипного характеру відповідних суспільних відносин. При цьому було враховано, що узагальненою вагомою особливістю норм права і норм моралі $€$ те, що концепт нормотворення у обох випадках опосередковано або прямо пов'язаний зі збереженням соціуму як сукупності індивідів, котрі перебувають у взаємозв'язку завдяки суспільним відносинам, що у своїй сукупності слугують основою виникнення, збереження та розвитку соціального середовища.

У контексті практичних особливостей цього дослідження закцентовано увагу на проблемах легалізації наркотиків та проституції як таких, що є практичним вираженням деградації норм права і моралі. Вказано на недоліки регуляторного впливу норм права на суспільні відносини за сучасних умов, а також закцентовано увагу на системному характері деструктивних тенденцій, пов'язаних з неврахуван-

( ) ВЕКЛИЧ В.О. - доктор юридичних наук, доцент кафедри конституційного права, історії та теорії держави і права (Навчально-науковий інститут права імені князя Володимира Великого Міжрегіональної Академії управління персоналом) 
ням сутності та значення норм права і норм моралі під час здійснення регулювання суспільних відносин на сучасному етапі розвитку.

Опрацьовано подібні та відмінні риси норм права і норм моралі, що мають практичну значущість, а також напрацьовано визначення деградації норм моралі та деградації норм права. Напрацьовано заходи превенції деградації норм права i норм моралі, що можуть застосовуватися за сучасних умов. Вказано на необхідність подальшої деталізації напрацьованих у цьому дослідженні заходів з урахуванням потреб практики спеціального характеру.

Ключові слова: норма моралі, норма права, легалізація наркотиків, легалізація проституиії, регулювання суспільних відносин.

This article contains the results of the research on the practical features of the legal norms and the moral norms under modern conditions, which are related to their regulatory impact on social relations. Some practical peculiarities of the emergence of moral and legal norms were outlined, as well as relevant theoretical material concerning the definitions of the mentioned norms. The general characteristic of social relations is presented considering the conditions of legal regulations' implementation in connection with mediation through generalized social relations' models. However, it was taken into account that a general significant feature of the rules of law and moral standards is that the concept of norm-making in both cases is indirectly or directly related to the preservation of society as a set of individuals that are interconnected due to social relations, which in their totality serve as the basis for the emergence, preservation and development of the social environment.

Special attention is paid to the problems of drug and prostitution legalization as an expression of the degradation of legal and moral standards in the context of the practical features of this study. The shortcomings of the regulation of the legal norms' influence over public relations under the present conditions are pointed out. The systemic nature of the destructive tendencies related to the neglection of the essence and importance of the legal norms and norms of morality in the regulation of social relations at the present stage of development is derived from practical examples.

Similar and distinct features of the norms of law and norms of morality, which have practical significance, were worked out, as well as special definitions of degradation of morality norms and degradation of legal norms. Yet there were worked out some measures to prevent the degradation of the legal norms and the moral norms, that can be applied under modern conditions.

Key words: moral norms, legal norms, legalization of drugs, legalization of prostitution, regulation of public relations.

Вступ. Правове регулювання за сучасних умов ситуативно зазнає впливу девіантних тенденцій. 3 урахуванням цього виникає потреба щодо практичного застосування теоретичного підгрунтя для попередження девіантних відхилень під час розробки правового інструментарію. Останнє вимагає базисного розуміння як теоретичних концептів норми права і норми моралі, так і можливих системних інструментів, які б убезпечили їх від можливої деградації. Вагомість цього визначається подвійною потребою як щодо довгострокового підтримання оптимальних для збереження суспільства суспільних відносин (об'єкта правового регулювання), так і щодо забезпечення розуміння базових концептуальних взаємозв'язків норм права і моралі під час реалізації відповідного правового регулювання.

На жаль, можна констатувати, що особливості норми права і норми моралі за сучасних умов $з$ практичної точки зору майже не досліджувалися.

Постановка завдання. У контексті поточного дослідження нагальним є реалізація подвійного завдання щодо окреслення загальних аспектів дієвості норм права і норм моралі під час регулювання суспільних відносин, що має поєднуватися з установленням потенційних заходів щодо превенції їх деградації («вихолощення» правової або моральної суті).

Результати дослідження. Норми права і норми моралі у їх практичному вираженні з урахуванням взаємозалежності фахівцями юридичної сфери майже не досліджувалися, а тому передусім слід звернути увагу на їх базові особливості. 
Л. Вакарюк, посилаючись на дослідження Л. Заморської, наводить таке комплексне визначення, яке було взято за основу під час здійснення нашого дослідження: «Норма права - це особливий вид соціальних правил поведінки загального характеру, що встановлені, визнані чи санкціоновані компетентним органом держави або в іншому, передбаченому нею порядку, які мають загальнообов'язкову силу, регулюють суспільні відносини в інтересах громадян і суспільства, виражаються публічно у формально-визначених приписах, зазвичай у письмовій формі, та передбачають можливість застосування державно-примусових заходів, включаючи відповідальність перед державою в разі порушення цих норм 3 метою їх підтримання та неухильного виконання» [1, с. 172]. О.В. Дєхтярьов і О.Б. Олійник навели дещо ширше визначення: «Норма національного права - це поведінка загального характеру, встановлена або санкціонована компетентним органом держави, що має загальнообов'язкову силу, регулює суспільні відносини в інтересах громадян та суспільства, передбачає відповідальність перед державою у разі порушення цієї норми» [2, с. 14].

У контексті цього дослідження передусім закцентовано увагу на моралі у ії загально соціальному значенні й розумінні, тобто на відповідному концепті, що презюмується як іманентно притаманний у минулому або сучасності значній частині людської цивілізації. Х. Слючарчук відзначила: «Існування групової моралі пов'язане з особистими контактами в групах, свідомим співробітництвом, спільним переслідуванням єдиних цілей, поширенням принципів колективістської моралі (солідарність, альтруїзм, групове прийняття рішень і так далі)» [3, с. 150-151].

Дещо узагальнене визначення було запропоновано 3. Сторожинською: «Моральні норми й принципи - це певні вимоги та заборони, що регулюють діяльність, поведінку людей, їхню взаємодію та спілкування» [4, с. 157]. Це визначення не можна вважати оптимальним, оскільки у ньому не було враховано деяких відмінностей, що існують між поняттями «норма» i «принцип», але разом 3 тим видається доречним узяти до уваги базові ознаки, які було наведено у цьому разі з урахуванням спеціальних рис, на яких було акцентовано особливу увагу в дослідженні цієї ж авторки: «Мораль - це форма громадської свідомості та вид громадських відносин, спрямованих на утвердження самоцінності особистості, рівноправності всіх людей у їхньому прагненні до щасливого та гідного життя. У моралі оцінюються не лише практичні дії людей, а й їхні мотиви, прагнення та наміри. Моральні вимоги до людини відповідають загальним нормам і принципам поведінки» [4, с. 146].

Розглядаючи поточну проблематику з практичного погляду, необхідно взяти до уваги спільні ознаки, що $є$ притаманними як нормам моралі, так і нормам права, які сутнісно належать до загальносоціальних норм. Так, у «Великому тлумачному словнику сучасної української мови» наведено таке визначення: «Норма - це звичайний, узаконений, загальноприйнятий, обов'язковий порядок, стан тощо. Зразок, правило поведінки людей у суспільстві» [5, с. 626].

Іншим важливим визначенням у цьому дослідженні $€$ «деградація». У згаданому словнику під нею розуміється «Поступове погіршення, втрата якихось якостей, властивостей; занепад, виродження» $[5$, с. 211$]$

Отже, можна констатувати те, що і норми права, і норми моралі мають подібні риси, оскільки вони $є$ видами соціальних норм. Сутнісною відмінністю $є$ забезпеченість відповідних норм 3 боку держави (класично тут акцентується увага на тому, що норма права «охороняється від порушень примусовою силою державного примусу» [6, с. 15]). Іншою відмінністю $є$ тривалість умовних «розробки та апробації» норм моралі, що виникають внаслідок багаторазового повторення і закріплюються в соціальній практиці як такі, що дозволяють оптимально убезпечувати соціум (або масив суспільних відносин) від деструктивних тенденцій або тих соціальних явищ чи процесів, які сутнісно $є$ шкідливими як для суспільства, так і окремих індивідів.

Вагомим $є$ практичне застосування теоретичних відомостей щодо норм права та моралі. Останнє має значну вагу через відсутність розуміння в окремих фахівців-практиків, а також громадян країни причинно-наслідкових зв'язків, які виникають у зв'язку з реалізацією регулювання суспільних відносин за допомогою норм права і моралі на сучасному етапі розвитку. Це спричиняє можливості для маніпуляцій з громадською думкою задля поширення деструктивних тенденцій загальносоціального характеру.

Так, окремі суспільні відносини за умови реалізації правового регулювання опосередковуються через узагальнені моделі з урахуванням однотипного характеру відповідних суспільних відносин (у контексті цього дослідження групи однотипних суспільних відносин розглядаються як умовні категорії суспільних відносин). Отже, органами державної влади щодо згаданих моделей суспільних відносин і здійснюється напрацювання нормативно-правової бази, яка підлягає практичному застосуванню. 
Виникнення норм моралі відбувається з урахуванням об'єктивного характеру суспільних відносин. У цьому разі передусім задіюються не органи державної влади, а поважні або впливові члени суспільства (соціуму), котрі вказують на можливі оптимальні варіанти соціальної взаємодії. Надалі практична реалізація відповідних рекомендацій дозволяє виявити ті моделі соціального регулювання суспільних відносин, які дійсно є оптимальними. Відповідні ж регулятори через тривале повторення починають набувати характеру норм моралі.

Узагальнено вагомою особливістю обох цих різновидів норм є те, що концепт нормотворення в обох випадках опосередковано або прямо пов'язаний зі збереженням соціуму як сукупності індивідів, котрі перебувають у взаємозв'язку завдяки суспільним відносинам, що у своїй сукупності слугують основою виникнення, збереження та розвитку соціального середовища. Таким чином, самі інструменти регулювання суспільних відносин, що виражаються у нормах моралі та права, значною мірою створюють передумови та слугують перешкодою для виникнення тих суспільних відносин, що можуть спричиняти безпосередню або опосередковану небезпеку суспільству, індивіду або ж масиву суспільних відносин. Так, стосовно норм права як основних ціннісних пріоритетів можна виділити принципи права, а також концепти прав та свобод людини і громадянина, а стосовно норм моралі - стан суспільних відносин, що $\epsilon$ оптимальним для довгострокового убезпечення соціуму, а також для розвитку і збереження окремих індивідів.

З урахуванням наведеного вище у контексті поточного дослідження зауважимо, що деградація норм права і моралі як регуляторів суспільних відносин має свої особливості, які мають бути врахованими:

1. Щодо деградації норм права - це фактична невідповідність законодавчих і підзаконних актів як форм вираження норм права принципам права, а також концепту прав та свобод людини i громадянина, що спричиняє зниження регуляторного впливу норм права на суспільні відносини.

2. Щодо деградації норм моралі - це звуження сфери поширення суспільних відносин, які $є$ оптимальним для довгострокового убезпечення соціуму, а також для розвитку і збереження окремих індивідів.

Для окреслення практичного вираження згаданих тенденцій з урахуванням поточного стану суспільних відносин слід взяти до уваги тенденції до «легалізації» окремих деструктивних явищ.

О.М. Миронець, Ю.О. Демченко і Т.Р. Атаманчук навели низку деструктивних наслідків, до яких може призвести легалізація наркотиків, зокрема, важливим $є$ такий аспект: «Вживання наркотичних засобів стане доступним для неповнолітніх осіб» [7, с. 40]. Вже сам факт легалізації у цьому разі спричиняє подолання внутрішнього «імперативу», який убезпечує більшість членів суспільства від вживання наркотиків та інших подібних до них речовин, тим самим провокуючи нівелювання відповідних норм моралі.

Іншим вагомим наслідком деградації норм права і норм моралі у наведеному випадку буде фактичне спричинення комплексних деструктивних наслідків окремим громадянам, масиву суспільних відносин та державі: «Варто зауважити, що вживання наркотичних речовин у будь-якому випадку матиме шкідливий вплив на організм людини» [7, с. 40]. Згаданий шкідливий вплив, виражаючись у зниженні інтелектуального та фізичного потенціалу осіб, котрі вживають шкідливі речовини, які можуть підлягати «легалізації», у підсумку матиме системне вираження у зниженні якості людських ресурсів, тим самим спричиняючи зниження надходження державного бюджету від оподаткування, а опосередковано - зниження темпів економічного зростання (зі зниженням ефективності регулювання суспільних відносин за допомогою норм права і моралі).

Іншим прикладом є легалізація проституції. Так, Г.С. Крайник, Д.В. Ревякін, Р.Є. Чорнобривець серед підстав для легалізації проституції вказують на наступну: «невідповідність Конституції України у зв'язку з тим, що не забезпечується ефективний захист життя та здоров'я осіб, які займаються проституцією (суперечить ст. 3 Конституції України)» [8, с. 711]. При цьому не піднімається питання щодо убезпечення таких осіб від зайняття вказаною діяльністю.

Порівняно грунтовніше дослідження легалізації проституції здійснили О.М. Миронець та I.O. Капустяк, котрі вказують: «Узаконення надання інтимних послуг за грошову винагороду у нашій державі $€$ передчасним і зумовить низку негативних наслідків для існування і здорового розвитку всього українського народу» [9, с. 30]. Так, легалізація у цьому разі спричинить зниження соціальної цінності індивіда і значення Конституції України, де у статті 3 зазначено: «Людина, iii життя і здоров'я, честь і гідність, недоторканність і безпека визнаються в Україні найвищою соціальною цінністю» [10]. При цьому сам факт легалізації проституції жодним чином не перебуває у зв'язку з забезпеченням державою відповідній категорії осіб окреслених соціальних благ. 
Натомість за поточної ситуації можна констатувати системну неспроможність держави забезпечити дієвий регуляторний вплив норм права на існуючий масив суспільних відносин. Особливістю дослідження, яке здійснили О.М. Миронець і I.O. Капустяк, є порівняно ширше опрацювання наслідків системного рівня щодо суспільних відносин. Зокрема, посилаючись на дослідження, яке провів С. Хендлін, вони відзначили: «Країни, у яких проституція є юридичним досвідом, збільшили показник торгівлі людьми, тобто між правовою проституцією та торгівлею сексом $\epsilon$ прямий зв'язок» [9, с. 30]. Так, у контексті легалізації проституції, окрім зниження соціальної цінності індивіда, було спричинено фактичну можливість для представників кримінального середовища уникати юридичної відповідальності, надавши частині своїх операцій умовного «квазіправового» характеру, що зовсім не знівелювало іншим аспектів злочинної діяльності, пов'язаної $з$ порушенням прав людини і громадянина.

Іншим прикладом деградації норм права та норм моралі $є$ фактичний стан суспільних відносин, що склався в окремих органах державної влади. Так, В.В. Гладкий зазначив: «Особливо негативними наслідками корупції $€$ те, що нею уражені державні органи, що створені та діють 3 метою забезпечування виконання покарання, зокрема, за вчинення корупційних злочинів» $[11$, с. 190]. При цьому на противагу радянській юридичній доктрині Лон Фуллер констатує: «Застосування чи незастосування сили не вирішує найголовніших проблем тих, хто видає та застосовує закони, - воно хіба що підвищує ставки» [12, с. 114]. Саме тому регулювання суспільних відносин має на практиці здійснюватися як за допомогою норм права, так і норм моралі, що на практиці повинно спонукати учасників суспільних відносин до підтримання соціальних відносин, які будуть убезпечувати соціум як середовище від деструктивних впливів.

Як можна побачити 3 наведених прикладів, фактичний стан суспільних відносин $є$ показовим у аспекті відображення теоретичних напрацювань у практиці соціального і правового регулювання у досліджуваній сфері.

До превенції деградації норм права і норм моралі за поточної ситуації можуть застосовуватися такі заходи:

1. Поєднання правового і морального (у загальносоціальному тлумаченні) аспектів вивчення наслідків втручання органів державної влади у масив суспільних відносин, які підлягають регулюванню.

2. Забезпечення вивчення системних причинно-наслідкових реакцій, що виникають у зв'язку з регулятивним впливом на масив суспільних відносин і не завжди стосуються безпосереднього предмета правового регулювання.

3. Забезпечити поширення правової пропаганди (пропаганди правових цінностей та орієнтирів), а також загальносоціальної моральної пропаганди в масштабах суспільства.

4. Забезпечити розробку правових інструментів нівелювання деструктивних впливів щодо правових та моральних пріоритетів та цінностей (передусім принципів права, а також концепту прав та свобод людини і громадянина) тощо.

Висновки. Дієвість норм права або моралі під час регулювання суспільних відносин фактично виражається у їх фактичній ефективності або ж об'єктивному регулятивному впливі на масив релевантних суспільних відносин. Відповідний вплив може залежати як від правових, так і від неправових чинників, які у своїй сукупності зачіпають різні аспекти регулювання суспільних відносин. Сфери моралі та права, перебуваючи у взаємодії, можуть бути використаними для системного підтримання позитивних щодо соціального середовища суспільних відносин, але разом з тим вони можуть зазнавати подібних деструктивних втручань, які спричиняють вихолощення (деградацію) їхньої суті та регуляторного призначення. Наведені у цій публікації заходи превенції деградації норм права і норм моралі мають системний характер і вимагають подальшого напрацювання спеціальних заходів, які б безпосередньо використовувалися під час регулювання суспільних відносин, а також задля убезпечення інструментів соціального регулювання (передусім норм права і моралі) від деструктивних посягань у діяльності фахівців-практиків.

\section{Список використаних джерел:}

1. Вакарюк Л. Норма права та правовий режим: співвідношення понять. Підприємництво, господарство і право. 2017. № 1. С. 171-176.

2. Дєхтярьов О.В., Олійник О.Б. Юридична природа та значення норми права. Збірник наукових праџь «Право та державне управління». Випуск № 4. 2018. С. 11-15.

3. Слючарчук Х.Т. Мораль та право в контексті полеміки лібералізму та комунітаризму. Європейські перспективи. 2015. № 4. С. 149-154. 
4. Сторожинська 3. Моральні цінності у житті сучасної людини Психологічні виміри культури, економіки, управління: Науковий журнал. 2016. Випуск IX. С. 146-157.

5. Великий тлумачний словник сучасної української мови / Уклад. і голов. ред. В.Т. Бусел. Київ; Ірпінь : ВТФ «Перун», 2003. 1440 с.

6. Могілевський Л.В. Сутність поняття «норма права». Прикарпатський юридичний вісник. 2016. Випуск 1. С. 14-18.

7. Миронець О.М., Демченко Ю.О., Атаманчук Т. Р. Теоретико-правові аспекти легалізації легких наркотиків. Електронне наукове фахове видання «Юридичний науковий електронний журнал». Запоріжжя, 2017. С. 38-40.

8. Крайник Г.С., Ревякін Д.В., Чорнобривець Р.Є. Окремі питання легалізації проституції та декриміналізації діяльності, пов'язаної з нею. Молодий вчений. 2018. № 4. С. 708-712.

9. Миронець О.М., Капустяк I.О. Теоретико-правові аспекти легалізації проституції. Порівняльно-аналітичне право. 2017. № 4. С. 28-30.

10. Конституція України: Верховна Рада України. Закон України від 28.06.1996 № 254к/ 96-BP. URL: http://zakon2.rada.gov.uaЛaws/show/254к/96-вр.

11. Гладкий В.В. Об'єктивні прояви пенітенціарної корупції. Науковий вісник публічного та приватного права. 2017. Випуск 6. Том 2. С. 187-192.

12. Фуллер Лон Л. Мораль права: пер. з англ. Н. Комарова. Наукове видання. Київ : Сфера, 1999. $232 \mathrm{c}$.

УДК 340.111.5:316.347

DOI https://doi.org/10.32844/2618-1258.2019.5-1.4

ГОЛОВАШ О.О.

\section{НАЦІОНАЛЬНА МЕНШИНА: СУТНІСНІ ОЗНАКИ ТА ЗМІСТОВНІ ХАРАКТЕРИСТИКИ}

У сучасному світі не існує держав, які б не мали на своїй території груп, які за своїми етнічними, расовими, мовними чи релігійними відмінностями відокремлені від більшості. Насправді у світі є біля 3000 етнічних або племінних груп, які усвідомлюють власні ідентичність та права. Отже, це проблема не тільки українського народу, але й усього світу. Навіть у сучасну епоху трапляються повідомлення про випадки геноциду окремих меншин. Відповідно до статистичних даних $\mathrm{OOH}$, майже 10-20\% населення світу належить до груп меншин та громад і лише $9 \%$ держав світу є технічно однорідними, з понад 190 суверенних держав, понад 175 є багатоетнічними за своїм складом.

У міжнародному праві комплексне визначення поняття «меншина» потребує уточнення та доповнення, незважаючи на те, що це питання неодноразово виносилося на форуми ООН починаючи з 1950 року. Багато держав таких, як Австрія, Чилі, Чехія, Словаччина, республіки колишнього СРСР, Гаїті, Угорщина, Індія, Румунія, Філіппіни, виступили проти єдиного визначення поняття «меншина». Отже, певною мірою небажання окремих держав, узагальнююче визначення такого надзвичайного важливого поняття, як «меншина», є однією з перешкод єдиного розуміння складного політико-правового явища.

Людство доволі жорстоко поводиться з меншинами, що призводить до несправедливої соціально-економічної сегрегації в окремих випадках. Однією з найважливіших причин минулих та сучасних етнічних криз у світі є той факт, що етнічні меншини виключені з участі у процесах розподілу влади та прийняття рішень в їх політичних системах. Формальні чи неофіційні домовленості щодо розподілу

( С ГОЛОВАШ О.О. - аспірант кафедри теорії та філософії права (Національний юридичний університет імені Ярослава Мудрого) 